\title{
Affective nationalism: Banalities of belonging in Azerbaijan
}

\author{
Elisabeth Militz *, Carolin Schurr \\ Universität Zürich, Winterthurerstr. 190, 8057 Zürich, Switzerland
}

\section{A R T I C L E I N F O}

\section{Article history:}

Available online 9 December 2015

\section{Keywords:}

Nationalism

Affect

Emotion

Embodiment

Feminist political geography

Affective methodology

Azerbaijan

\begin{abstract}
A B S T R A C T
While Michael Billig's 'banal nationalism' points to the significance of the trivial reproduction of national representations in everyday routines, feminist political geographers have highlighted how the nation is brought into being through embodied and emotional practices. Building upon and extending these notions of the nation as represented and embodied, the paper argues that the nation also takes shape through bodily encounters and joyful as well as painful affections. In what we call 'affective nationalism', the nation emerges in moments of encounter between different bodies and objects through embodying, sharing, enjoying or disliking what feels national. We combine a Deleuzian reading of affect that discloses the mechanisms of material becomings with feminist scholarship sensitive to how bodies affect and are affected differently by materially produced nationalisms. Based on ethnographic field research in Azerbaijan, which we present in three vignettes, we untangle the affective becoming of national bodies, objects and places during a publicly staged ceremony of the collective remembrance of martyr and the celebration of a national holiday within the realm of a family. The paper makes two contributions to researching affective nationalism. First, it enquires into how people identify with Azerbaijan through their capacities to affect and to be affected by what feels national and, second, it explores how affective nationalism can be captured through vignettes of affective writing.
\end{abstract}

(c) 2015 Elsevier Ltd. All rights reserved.

\section{Introduction}

The bustle makes me feel exhilarated. Hundreds of cheerful people crowd on the wide Büyük Gala street in the old town of Baku. In one corner a tightrope dancer prepares for his grand entrance. In another, a crowd of agitated people draws closer around a troupe of jugglers. The audience cheers them on with sporadic Aaaaahs and Ooooohs.

Through the speakers I can hear the entertainer announcing the next act. A formation is about to dance one of the most popular Azerbaijani dances, the yalli. About 20 girls and boys wearing colourful and glittering costumes run onto the stage. They line up holding hands and as soon as the brisk music begins, they move their legs back and forth and their hands up and down, the 20 dancers merging into one through the coordination of their movements. Then, they form a circle and whirl to the right. A squawking wind instrument plays fast runs as the rhythmic drumming grows ever more intense.

\footnotetext{
* Corresponding author. Department of Geography, Universität Zürich, Winterthurerstrasse 190, 8057 Zürich, Switzerland. Tel.: +41 774092476.

E-mail address: elisabeth.militz@googlemail.com (E. Militz).
}

As I look around, I see people enjoying the dance performed on the stage. Some rock their bodies to the rhythm. Some 20 meters in front of the stage, I observe people making room in the crowd. Some teenagers start holding hands and while circling right move their hands up and down and their legs back and forth. They dance in the same way as the performers on the stage with one difference: they haven't organised themselves to dance before. They also look like their dancing excites them more. The girls and boys on the stage make an effort to maintain their stiff posture and keep a uniform grin. The teenagers from the crowd burst out laughing, one boy tosses back his head and while their dance is picking up speed they beam with joy (field notes Elisabeth from 21 March 2014, Baku).

If Michael Billig (1995) is right that nationalism is banal, this scene in Baku, Azerbaijan, reveals more than mere amusement. With Billig, the teenagers on the Büyük Gala street perform the yalli as a marker of a distinct Azerbaijani national culture. The dancers reproduce Azerbaijan in the moment of recognising the dance as part of an imagined "we". Fundamental to Billig's banal nationalism is the idea that people feel a sense of national belonging through everyday practices such as a national style of dancing. Revealing 
how these everyday national practices are tied to bodies, feminist political geographers have developed the notion of "embodied nationalism" (Mayer, 2004; McClintock, 1995; McClintock, Mufti, \& Shohat, 1997; Radcliffe, 1996). They have studied dancing (Nash, 2000), dressing (Nelson, 1999), or styling (Faria, 2013, 2014) to understand how the nation unfolds through embodied gender performances.

Yet, the situation above discloses more than Billig's banal nationalism or feminist political geographies' embodied nationalism allows us to see. What motivates the teenagers to move their bodies in coordinated rhythms in the first place? There is, we argue, an affective component binding bodies together - a situational configuration of noises, odours, objects, and memories. The dancing, as a contingent and temporary configuration of different bodies and objects, has the potential to affect, to unify differently marked bodies, and thus to create something new, such as a feeling of national belonging.

Three aspects mark out the affective moment of the yalli as national. First, corporeal reactions such as the spontaneous dancing of the teenagers are bound up with knowledge and past experiences referencing a collective shared feeling of the "imagined community" (Anderson, 1991) of a nation. As Sara Ahmed (2004a, p. 171) has argued, the politicisation of emotions binds bodies together or sets them apart. Second, the affective encounters of the dancing bodies on the Büyük Gala evoke enjoyment. This enjoyment of what feels national encompasses both happiness and anxiety. While the teenagers rejoice in the experience of what feels like national dancing, observers of the scene who feel different about those embodied national representations might as well encounter a sense of exclusion. Fantasies of a unique nation emerging from the momentary configuration of bodies and objects stimulate the constant reproduction of enjoyable as well as menacing experiences of the nation. Third, affect is national here because the idea of the nation through a national way of dancing (Bryant, 2005; Kaschl, 2003; Zhemukhov \& King, 2013) is intertwined with its rhythmic incorporation. Even though bodily experiences of national affection are as diverse as different bodies (ToliaKelly, 2006), what feels national emerges in the affective space between bodies created through the music and rhythm of the yalli dance.

In this paper, we propose the notion of an affective nationalism - the banal affirmation of the national emerging in moments of encounter between bodies and objects. Bringing into dialogue a Deleuzian interpretation of affect (de Spinoza, 1883; Deleuze, 1988) with feminist approaches to affect, bodies and becoming, we acknowledge bodily markedness and different affective capacities (Colls, 2012; Tolia-Kelly, 2006; Wetherell, McCreanor, McConville, Barnes, \& le Grice, 2015) as central characteristics of an affective nationalism. With our idea of an affective nationalism, we expand notions of banal, embodied and emotional nationalisms to reveal how processes of national signification grip different bodies, effecting sentiments of national belonging and alienation.

We begin by revisiting how (feminist) political geographers have approached the study of nationalism as banal, embodied, and emotional. We then illustrate our proposition of an affective nationalism, before we present our methodological approach of affective writing. Drawing on ethnographic research in Azerbaijan, we then highlight how collective bodily experiences of sharing, enjoying or disliking (re)produce an affective nationalism.

\section{Nationalism revisited: banal, embodied, emotional}

In Banal Nationalism, Billig (1995) argues that nation states are unknowingly reconstituted in banal everyday practices through which people constantly reproduce their nationhood. Billig searches for the banal dimensions of nationalism in symbolic representations of the national, such as the daily flagging of the nation, the use of shared languages, or the daily reference to the weather "here" (p. 116) in the news.

In political geography, scholars have echoed Billig's (1995) concerns with the mundane making of the nation in two ways. First, political geographers have explored how social practices mark out banal nationalism (Benwell \& Dodds, 2011; Jones \& Desforges, 2003; Paasi, 1996). They have analysed the inconspicuous manifestations of nationalism such as postage stamps (Raento \& Brunn, 2005) and banknotes (Penrose, 2011), road signs (Jones \& Merriman, 2009), license plates (Airriess, Hawkins, \& Vaughan, 2012; Leib, 2011), supporting national sport teams (Koch, 2013) and national maps as in school textbooks and flag-map logos (Batuman, 2010).

Second, feminist scholars have explored Billig's banal nationalism highlighting how the nation emerges through embodied gender performances in everyday life (Mayer, 2000; Staeheli, 2001; Warren, 2009; Yuval-Davis, 1997). With the notion of an "embodied nationalism" (Mayer, 2004), they have challenged the disembodied and abstract nature of much nationalism research in political geography (Blunt, 1999; Fluri, 2008; Hyndman, 2004; Radcliffe, 1999). Examining the political "through the scale of the body" (Dowler \& Sharp, 2001, p. 169) and asking how "citizenship is embodied" (England, 2003, p. 615), feminist political geographies have interrogated how the nation is "affected by and reflected in embodied practices" (McDowell, 1999, p. 35). They have investigated how the nation is embodied in such diverse sites as reproductive politics in India (Smith, 2012), women's gender performances in Israeli's occupation (Mayer, 1994), rape as an embodied form of warfare in former Yugoslavia (Mayer, 2004), gender performances in Ecuadorian electoral politics (Schurr, 2013a), and the staging of the new nation South Sudan through beauty pageants (Faria, 2013). While not always focusing on the nation as the main scale of analysis, feminist political geographies advance our understanding of the importance of embodied practices in shaping the national body.

Feminist scholars have advanced research on nationalism by emphasising its emotional dimension (Berlant, 2008). While political geography was initially hesitant to incorporate the emotional turn into the subdiscipline (Pain, Panelli, Kindon, \& Little, 2010, p. 973 ), in the meantime a rich body of literature under the labels of emotional geopolitics (Pain, 2009; Tyner \& Henkin, 2015), intimate geopolitics (Smith, 2012), and emotional political geography (Wilkinson, 2009) has emerged. Caroline Faria (2014, p. 319) points out that the emotional turn in geography offers "rich opportunities to rethink nationalism". She argues that "nationalism is emotional - marked at once by contradictory feelings of fear and desire that require, and indeed depend on, a foreign other" (Faria, 2014, p. 318). Her work on the becoming of the South Sudan nation demonstrates that nationalism needs to be understood as a feeling of connection, belonging, and attachment to the collective body of the nation as well as detachment from those outside of or threatening the nation.

We both build on and expand (feminist) political geography's engagement with banal, embodied and emotional nationalisms by inquiring into the affective nature of feeling a national belonging. ${ }^{1}$ A focus on the affective dimension of nationalism serves to analyse the emergence of feelings of national belonging. The paper asks how materially produced national representations affect different bodies: First, national sentiments arise through a specific assortment of elements that stimulate the emergence of certain feelings and practices. Second, through this assortment of elements, different bodily histories become relevant in moments of affection and enable feelings of proximity and distance. Lastly, this embodied becoming of national meaning connects different bodies with multiple capacities to affect and to be affected through sentiments 
of belonging and alienation.

\section{Affective nationalism}

In our understanding, affective nationalism is the quotidian affirmation of the national through momentary encounters of bodies and objects. Following Ben Anderson (2014, p. 17) in recognising that "affect is simultaneously [a] [...] bodily capacity and collective condition", nationalism is affective through embodying, sharing, enjoying as well as disliking what feels national. Ahmed's (2004a) work is crucial for our understanding of affective nationalism as it shows how declarations of shared feelings such as shame bring the nation into existence. While Ahmed traces the affective impact on bodies and the production of national feelings through texts, she does not conceptualise how affections work. We extend her argument by untangling the assortment of elements in moments of affective encounter and by revealing how encounters between different bodies and objects bring mundane national practices into being.

To tackle these questions emerging from an understanding of nationalism as affective, we draw on a Deleuzian notion of affect that has recently gained popularity among political geographers (Müller, 2015; Pile, 2010; Thrift, 2004) interested in investigating the affective constituents of (geo)politics and the state (Carter \& McCormack, 2006; Ó Tuathail, 2003; Woodward, 2014; Yea, 2015). In our paper we develop an understanding of affect that combines Deleuzian and feminist approaches. Three assumptions are crucial for our conceptualisation of affect: (1) affect results from transpersonal relations between bodies and objects; (2) different bodies have different capacities to affect and be affected; (3) constant processes of becoming make for bodily encounter and thus affection. Let us explain each of these points.

First, in a Spinozian understanding (de Spinoza, 1883; Deleuze, 1988; Deleuze \& Guattari, 1987, 1994; Hardt, 2001; Massumi, 2002), affection as the process and affect as the result of corporeal encounters between bodies and objects are the forces that make for the emergence of more-than-human configurations. Bodies and objects are not defined by their substance but by their encounters, by their "capacities for affecting and being affected" (Deleuze, 1988, p. 124).

Second, feminist scholars have called attention to the way "different bodies hav[e] different affective capacities" (Tolia-Kelly, 2006, p. 213) to affect or to be affected. "Through their racialized, gendered and sexualized markedness" (ibid., p. 215), everybody is its "own peculiar conjuncture of history, gender, ethnicity, age and education" (Waterton, 2013, p. 77). Despite different biographies and perceptions, the power of affective nationalism lies in its ability to enrol people into reproducing specific national practices. Affect becomes a powerful tool for the manipulation of political desiderata because it relies on the unpredictable, yet ordinary contact between historicised bodies and objects (Sharp, 2009; Thrift, 2004; Waterton \& Watson, 2013). In affective encounters, difference hence becomes a central condition for the integration of bodies and objects into collectives (Ahmed, 2004b). Anne-Marie Fortier (2010, p. 22) describes this potential to fuse different bodies together as "governing through affect".

Third, conceptualising "each individual [body and object as] an infinite multiplicity" (Deleuze \& Guattari, 1987, p. 254), the idea of 'becoming' is central to a Deleuzian notion of affect. Following Rosi Braidotti's (1994) interpretation of this Deleuzian idea of becoming allows understanding how bodies with different affective capacities get stimulated to melt into feelings of sharing and collectivity. While subject positions - as different modes of being - develop from bodily becomings, differences between them are immanent to their materialisation (Braidotti, 2003). In the moment that bodies, objects or places meet and resonate with each other, bodily histories such as past experiences are activated as well. Bodily differences are tied to processes of affective becoming through generating, activating, and altering bodies, objects or places in moments of encounter. Braidotti (2002) enhances Deleuze's perspective on bodily becomings by explicating the process of 'becoming different'. Referring to Deleuze and Guattari's (1987, pp. 105-106) idea of "becoming-minoritarian", she highlights the multiplicity and asymmetry of bodily creations constituting subjects and thus different affective capacities.

How does such an understanding of affect advance conceptualisations of nationalism as affective? Initially, affect as a transpersonal, bodily capacity triggers the contingent combination of bodily experiences to generate something new. Reconstructing moments of affection allows us to show, for example, how places inspire the rise of bodily sentiments to feel included or excluded at national heritage sites or national monuments. The way in which what is identified as a national heritage site is being represented through specific arrangements of objects, fabric, colour, and patterns aims at communicating what counts as national and deserves particular attention and protection. As a consequence, the deliberately manufactured bodily encounters between places, objects, memories, and visitors incite feelings of belonging in some, whereas it may evoke feelings of exclusion in others (Crang \& ToliaKelly, 2010; Waterton, 2013).

The phenomenon we refer to as nationalism thus does not simply pre-exist but becomes relevant as a mixture of feelings compromising positions of proximity and distance in moments of affective encounter between different bodies and objects. Instead of solely concentrating on the banal, embodied and emotional elements of national identification, our concept of affective nationalism enables us to follow the processes that effect feelings of national belonging and alienation as a continuous flow connecting different bodies. Visceral experiences such as preparing and eating traditional dishes mark this affective becoming of bodies, objects and places.

In addition, recognising that "any encounter contains reference to past encounters" (Anderson, 2014, p. 82) allows us to understand how moments of affective encounter might infuse various bodies with disparate affective capacities to feel a sense of national collectivity. Jason Dittmer (2014) argues that communities emerge as the aggregation of individual bodies, such as when the nation as a whole feels shocked by systematic rapes of women (Mayer, 2004). A shared feeling of national belonging also works, for example, through gesticulating in a specific manner in a certain place, at a certain time with a certain arrangement of bodies and objects (Darling, 2010) or through putting on a uniform (Adey, 2011). Such affective practices (Wetherell, 2012) - that we understand as bodily articulations sparked by as well as stimulating resonance with surrounding bodies, objects, and places involved in affective encounter - effect a shared sense of national belonging. The moments of affective becoming trigger negative as well as positive feelings depending on the bodily histories they stimulate. Tingling with excitement when expecting the final score of an international football match, for example, conveys how the enjoyment of what feels national anticipates feelings of satisfaction and aversion or menace at the same time (Kingsbury, 2011; Proudfoot, 2010).

Furthermore, focusing on the becoming of national bodies, objects, and places reveals how the unpredictability of affective encounter (re)produce nationalist sentiments. The illusion of the nation unfolds in situational configurations of different bodies, objects, places, and memories. Volatile and unexpected encounters constitute processes of becoming of national bodies and the rise of feelings for the nation. Natural or social catastrophes such as an earthquake or war, for example, put the inviolability of national 
bodies and territories at risk. Corporeal encounters with the disaster fuel feelings of threat and a sense of alignment with the imagined national community. Television pictures illustrating the catastrophe collide with corporeal histories, the voice of the journalist, the sight of a face filled with fear and thoughts circling around questions about one's own vulnerability and incite sentiments of attachment to intimate bodies constituting the nation. Even struggling to resist practices or feelings of national connection, we cannot help but reinforcing them at the same time. Appreciating the contextual eruption and immanent differentiation of bodily becomings then allows us to conceptualise nationalism as powerful moments of affective encounter that enable the alignment of different people, places and objects with feelings of national belonging and alienation. Turning to the affective moments of national identification uncovers how the persistence of nationalism is due to its potential to unify people despite individual experiences and bodily histories.

Our core interest in studying affect thus lies in detecting how the nation emerges from moments of affective encounter between different bodies and objects. Drawing on ethnographic material from Azerbaijan, we demonstrate how moments of affection stimulate feelings of national belonging and alienation through embodying, collectively sharing, enjoying and disliking what feels national.

\section{Experimenting with an affective methodology}

Researching affect resembles an experiment (Dewsbury, 2010). Our methodological approach has opted to employ the body rather than texts - as an essential research instrument (Longhurst, Ho, \& Johnston, 2008). The goal for the researcher is to experience what affects and is affected and to aim at "presencing" the results; that means to render the affections in certain situations able to be experienced (Müller, 2015). As a methodological consequence, we conceptualise the various bodies of the researcher (for example the physical body, a gesture or thoughts) and their emotionalities as generative elements of affective encounter (Bondi, 2005a). Hence, the researcher's empathic capacities (Bondi, 2014; Jones \& Ficklin, 2012), emotional entanglements (Lobo, 2010; Schurr \& Abdo, 2016), and reflexivity (Faria \& Mollett, 2016; Rose, 1997) shape the data generated within the research process.

To experience affective encounters that trigger nationalism, our methodology of choice is an autoethnographic account centring on affective experience (Butz \& Besio, 2009; Moss, 1999; Waterton \& Dittmer, 2014). An affective methodology aims at eliciting affective experiences that "give a sense of the process of becoming implicated in and faithful to the relations, movements and objects" (McCormack, 2003, p. 503). Just as the feeling for a shared belonging to an imagined national community counts as a moment of affection, the processes of writing, reading and thinking about what has been written constitute a course of becoming (McCormack, 2003).

Feminist geographers in particular have contributed methodological accounts recognising the embodied places of knowledge production. They have put forward video recordings (Schurr, 2013b), autobiographical reflections about emotional responses (Smith, 2016; Watson, 2012), and psychoanalytic methodologies (Bondi, 2014) as methodological tools to access body language and feelings for analysis. For Hayden Lorimer (2005, p. 89), research on affect needs to be able to yield the "thickest, anatomical descriptions of doing". Those illustrations cannot reproduce the experience. They can, however, help to pave the way to the reader's, observer's or listener's mind (Bondi, 2005b).

To allow the reader an experience of the affective encounters producing feelings of national belonging and alienation, national enjoyment and national bodies, we have composed texts in the style of vignettes. We conceive of vignettes as the written output of a thick description of moments central to the research. To reveal the mechanisms of an affective nationalism, the vignettes disassemble the bodies, objects and places involved, at the same time as they convey ideas of how to make sense of the bodily relations. In other words, vignettes as research tools condense what the researcher experiences during the field research (Ely, Vinz, Anzul, \& Downing, 1997).

Vignettes seek to achieve two things: First, they try to be transparent about the researcher's perspectives by situating the researcher within the moment of affective encounter. In that moment the researcher becomes a story-teller who abstains from speaking for anybody but for herself. The researcher's bodily histories influence the affective capacities of bodies involved in the research process and as a consequence also what attracts the researcher's attention and what remains neglected. Second, vignettes intend to trigger affective experience in the reader. Our idea of an affective nationalism and how materially produced national representations affect bodies in Azerbaijan emerge from the encounter with the written texts.

This paper relies on extended and repeated periods of ethnographic field research in Azerbaijan between 2012 and 2014. The "I" in the following vignettes refers to the first author of the paper, who conducted the empirical research in Azerbaijan. While in the field, I spent most of the time with one family (and their circle of kin and acquaintances) in Baku, the capital of the Republic of Azerbaijan. What I experienced in the family and what the family brought to my attention, therefore, informs my research. As a result, my encounters generated my research data. About half the people I met in Azerbaijan had known me, my research trajectories as well as my social networks for several years. ${ }^{2}$

In addition to bodies and objects involved in affective encounters, places, too, “discharge" (Navaro-Yashin, 2009, p. 4) stimulations. Thus, the places of the research and the presence of the researchers' various bodies shape the research narrative. This begs the question of whether the inevitability of different bodily capacities to affect and get affected makes researching affect impossible. In the case of this research, my bodily capacities to affect and get affected influenced what and whom I encountered in the first place. At the same time as this facilitated contact and participation in family lives, it prevented encounters with other people, objects and places. These affective becomings remain untold because researching affective nationalism is predicated on bodily capacities.

\section{Affective dimensions of national belonging in Azerbaijan}

Why should we research affective nationalism in Azerbaijan of all places? The standard response to this question would point to the central role of nationalism in nation-building processes in the transitional times of post-Soviet space and Azerbaijan in particular (Beissinger, 2002; Müller, 2011; Smith, Law, Wilson, Bohr, \& Allworth, 1998), to the two rivalling national ideologies of Turkism and Azerbaijanism (Tokluoglu, 2005) and to the recent reinvigoration of national cultural traditions such as in music and dance (Naroditskaya, 2005; Valiyev, 2005) - all of which underscore the importance of nationalism in its multiple manifestations in Azerbaijan. We decided to study affective nationalism in Azerbaijan because we noticed that while questions of national belonging and debates of what is or should be the nation in Azerbaijan are of remarkable topicality, people's lived identification is often at odds with the official nationalism promoted by the state.

In fact, as our reasoning will show, people feel a belonging to Azerbaijan in banal moments of affective encounter between specific places, different bodies and objects. 
In the following, we present two vignettes guiding us through varieties of affective nationalism in Azerbaijan. Whereas both illustrate how transpersonal flows connecting different bodies and objects constitute forms of affective nationalism, each analysis highlights particular aspects of national affections. Whereas the first vignette focuses on the affective becoming of national bodies, objects, places and how affective practices render feelings of belonging and alienation, the second vignette reveals how the embodied and visceral enjoyment of what feels national effects a sense of sharing.

\section{"It's like the music is crying"}

The first vignette evokes the collective remembrance of the events of January 1990 in Baku. Following an increasing mobilisation among Azerbaijanis to rally for the national and territorial integrity of the country in the late 1980s, the Soviet government sent tanks into Baku on the night from 19 to 20 January 1990 in an attempt to maintain political control. 168 civilians were killed and a few hundred injured as the troops proceeded to obtain control over the city (Sayfutdinova, 2014). Judging from the gravestones at the cemetery displaying the pictures of the dead set in the polished granite, most of the victims were young to middle-aged men.

Everybody I spoke with identified 20 January as the most important national mourning day for Azerbaijanis. Some respondents also mentioned the day's importance in the celebration of Azerbaijan's independence. People's identification of 20 January as a day of national independence corresponds to the idea that the intention of the military intervention of Soviet troops on 20 January 1990 was designed to smother nationalist fervour. This nationalist fervour played a prominent role in justifying ethnic cleansing and violent retaliation during the conflict between the Azerbaijan SSR (Socialist Soviet Republic) and the Armenian SSR over the political annexation of the Nagorno-Karabakh Autonomous Oblast in the late 1980s (De Waal, 2003; Sayfutdinova, 2014).

On 20 January 2014, I accompanied a youth group on their procession to the martyrs' alley in Baku. This group, consisting mainly of university-educated men between the age of 20 and 35, is one of the few known activist groups in Azerbaijan. Members describe themselves as interested in the democratisation of the country. With the help of my family connections, I contacted one of the activists who then invited me to join the group for the walk along the martyrs' alley. At that day only one other female member of the group joined the collective march and I happened to walk next to her.

I am walking next to Samira. ${ }^{3}$ She joined our group some minutes ago, greeting everybody with effusion and pecking them on their cheeks. I don't know her, but she is so outgoing and I instantaneously take her into my heart. She hands me a red carnation and asks me to drop it on one of the graves on the martyrs' alley. We are moving in silence towards the alley. The street is closed to traffic and it feels almost intimidating to walk on this wide, four-lane road. All the people are marching in the same direction, with the same intention, the same pace, the same purpose.

As we start walking, it is just the echo of our steps and the murmur of voices that hang in the cold air. But as we are heading for the monument, we hear a slow-moving, whining music: a high-pitched wind instrument combines trills and disharmonic sound sequences. High-build speakers carry the sound along the alley and the neighbouring cemetery.

I bend over to Samira. I don't want to drown the music and ask her in a soft voice:

"What kind of music is this? Why do they play it?"
"This is Mugham. They are playing it for the sadness."

She frowns and then hesitates as if looking for the right words to describe what she is feeling.

"They play this music so that people can feel the sadness."

She pauses.

"You know, we lost many people 24 years ago. It is part of our culture that they play this music. It is our national music and today is a day of sadness. The music is like it is giving you sadness. You listen to it and then you feel sad about what happened."

I think about what she just said and wonder about the sadness of the moment. Do I feel sad? I feel compassion.

"Are you feeling sad?", I ask.

"Me? Because I am Azerbaijani by blood, you know, I am feeling it in my blood. The music is in my blood. As soon as I hear the music, it is in my heart and my heart is broken. Yes. I lost many people here, children, youth, adults... It is like the music is crying."

She pauses as if following the stream of music running through her veins right into her heart exhausts her talking.

We keep on walking.

All of a sudden, about two-dozen men exclaim in unison "Allahu Akbar! Allahu Akbar!" somewhere behind us. I turn around.

The resolute calls irritate me. I have barely experienced public statements of faith in Baku so far.

I look at Samira and some of the boys from the youth organisation. I try to read their faces. I am searching for traces of approval or dislike, but most of them look indifferent. If at all, some of them look annoyed. One boy grimaces in disgust. The moment leaves me confused.

We have almost reached the graves of the alley. Nobody is talking anymore. The rhythmic sound of our steps trails away and the Mugham music fills the cold air with a touch of sadness. I take a deep breath and look around.

On top of a high flagpole, I see a big Azerbaijani flag dancing in the wind. At the entrance of the alley, the masses of people pass a flame and arrangements of red flowers. I notice the uniformity of the crowd and the shared, coordinated acting. I carefully try to act the same. It increases my feeling of solidarity with the people around me. But I will probably never feel the same intense sadness as Samira, since those are her people who died 24 years ago for her country and not for mine (field notes Elisabeth from 20 January 2014, Baku).

The march down the martyrs' alley takes place in an atmosphere of shared feelings of both grief and pride. Samira mourns the people who died on 20 January 1990 . At the same time, she feels proud to be Azerbaijani, to be part of the strong "we".

These feelings of joy and grief emerge from the momentary configuration of bodies and objects such as the Mugham music in the background, the red carnations, bodies moving with each other, the sound of their uniformity, and the anticipated encounter with the graves covered under masses of red carnations. In this stimulative flow of encounter, the bodies, objects as well as the place become through the activation of a plurality of bodily histories. Gendered becomings constitute this predominantly male commemoration ceremony. As I observed at the majority of events conducted in public space - in contrast to activities in private space - the larger share of participants is male. The youth group I am accompanying is predominantly male as is the group of believers calling on Allah. Furthermore, the buried bodies are personified as mainly male martyrs, composing a male martyrdom.

The specificity of the place, the Alley of Martyrs, contributes to this moment of affective becoming as it renders national 
significance. The alley extends on a prominent elevation southwest of the city centre of Baku. Climbing up a couple of dozen of stairs at the entrance of the passageway where a big Azerbaijani flag is flying in the wind, you see yourself confronted with the sight of a long alley clad in clean, wheat-coloured sandstone. The portraits and names of the victims of 20 January 1990 are engraved in anthracite-coloured, polished marble plates lining the lane towards a sandstone tower. An eternal flame flickers in the centre and illuminates the tower's ornamental cupola. Green conifers cover the cemetery below the alley. The Alley of Martyrs becomes in the moment of encountering the purposeful selection and arrangement of different objects, colours and materials. The tombstones give Azerbaijani people a face and a history, the flag marks it as Azerbaijani territory, the Mugham music takes possession of the air and the absence of anything that could interfere with the becoming of this national site ensures the intensity of affective stimulation. As the specific assortment of elements encourages thoughtfulness and consternation the connection of different bodies at a time, such as the visitors, the marble graves, and the eternal flame boosts the felt distinctiveness of this heritage site. The alley becomes in this momentary configuration of bodies and objects and thus makes the Alley of Martyrs a place where the Azerbaijani nation becomes experienceable. At the same time, spiritual and gendered differences in people's experience of the 20 January commemoration reveal how the situational becoming of this national heritage site is contested. The moment of bewilderment following the believers' invocations of "Allahu Akbar!" suggests bodily varieties of affective stimulation as well as disputed embodiments of national representations.

In the moment of experiencing the commemoration march, I came to understand how affective capacities differ. By showing compassion instead of grief, I find myself blending Samira, the other people around me, and the buried bodies into a conglomerate of bodies constituting the Azerbaijani nation. Confirming my cultural Otherness, this moment of affective encounter, more than any other situation, makes me feel different from the bodies around me. I recognise the Azerbaijani nation in the shared sadness and people's placid coordination of movements. Even though the situation prompts different thoughts and feelings in me than in the other people around me, I feel affected by the moment - this particular configuration of bodies and objects around me such as the music, the marching people, and the tombstones. In a bizarre and incomplete way the joint march along the alley makes me feel corporeally connected to the bodies surrounding me. At the same time, feeling uninvolved with the national history and a lack of biographical significance of 20 January 1990 leaves me with a sense of disconnection.

Samira, on the contrary, feels connected to others; she talks about how "we lost many people" and about "our culture" and "our national music". The situation as well as the practices incorporated by the different bodies marching down the alley seems natural to her. It even constitutes her body when she, later on, refers to the music being in her blood and in her heart.

The encounter between different bodies and objects constituted through affective practices such as the synchronic marching, laying red carnations on the graves as well as invoking Allah, allows for sensing those collective connections - despite the simultaneousness of different bodily experiences of what feels national - as well as disconnections. Incorporated mundane practices stimulate different bodies to resonate with each other. With Ahmed (2007, p. 156), the bodies act "habitually", as they repeat learned commemoration practices in their unexceptional performance of routines. Repetitions of learned practices such as dropping red carnations on the tombstones, remembering the dead together with others or keeping silent while visiting a commemoration emerge as corporeal articulations of the national. These embodied practices produce what is perceived as national affected by the idea to commemorate martyrs who are understood as people who died for the nation. Bodily actions as "somatic memories embedded in us [and other bodies] through socialization processes over many years" (Waterton \& Dittmer, 2014, p. 133) help to ensure the "sacred quality" (ibid.) of the Alley of Martyrs.

What is more, the conception of an Azerbaijani nation being victimised and thus vulnerable becomes present as a felt reality when passing the graves and gazing at the engraved faces of the dominantly male - dead whose carved eyes rest innocently but remorselessly on the passers-by. The moment the victims of 20 January were buried and are remembered as martyrs, the dead bodies become the "body of the nation" (Ahmed, 2001, p. 365). As "a shared 'object of feeling' " (Ahmed, 2004a, p. 13, quotes in original) the nation arises as a vulnerable body of love (ibid., p. 130) in moments of affective encounter. Joyful feelings of belonging are thus bound up with bodily histories of suffering.

The music in the background plays a key role in sparking those sentiments. As a culturally scripted sound that combines specific tone sequences and instruments the music bears the potential to trigger feelings (Wood, 2002, p. 69). The sound floats between different bodies, connects them and thus enables felt experiences of something shared. We thus recognise the music as a kind of contagious power stimulating affective practices. The momentary encounter of bodies and objects converts the march down the martyrs' alley into a "public sphere of collective intimacy through which official mass nationality stays familiar" (Berlant, 1997, p. 179). The feeling of sharing national grief and pride results from feeling an intimate belonging.

The assumption that affective dispositions are universal (Waterton, 2013) towards what feels national guides the formal composition of the commemoration process on 20 January to mourn a male martyrdom. The arrangement of bodies and objects such as the Mugham music, the red carnations, the site of tombstones portraying pictures of the dead, the Azerbaijani flag, masses of people visiting the place at the same day aims at inducing feelings of national belonging, pride and grief. The prevalence of one way of commemorating the dead and remembering historical milestones of the national development, however, is problematic. Alternative assessments of the historic events become inappropriate or even wrong such as when the group of men somewhere in the crowd praying to God caused people in my company to show their dismay.

The example of this ritualised commemoration in Azerbaijan shows how processes of becoming in a more-than-human flow and varying bodily capacities for affection effect the momentary emergence of a community of shared feelings in bodily encounter. Central is the idea of experiencing this embodied knowledge of belonging to a distinct national community through joyful as well as painful affections.

\section{"We are kind of shining from inside"}

The second vignette features Novruz Bayramı, the most important holiday in Azerbaijan. Celebrating the holiday throughout March, culminating at the spring equinox on the Northern hemisphere, the basic idea of the festivities is to welcome spring. In contrast to the majority of other holidays, it is neither a Muslim holiday nor a political holiday. Although it has become more and more commercial with free entertainment shows, one week off from work for civil servants and special holiday deals in supermarkets, people prefer to celebrate Novruz Bayramı with their families. The holiday involves specific food and rituals and everybody I talked to honoured it. It was not uncommon for my 
interviewees to say something like "I love Novruz. It's my favourite holiday!" The following vignette recalls a conversation between my host mother Elnara and me about Novruz Bayram, which situates this enthusiasm.

Elnara is a well-educated mother in her mid-twenties. She grew up in a middle-class household, enjoyed a university education, studied abroad and, at the age of 25 , married Ilgar who has been the bread winner for the family ever since. They have a one-year old daughter, Leyla. Elnara and Ilgars' marriage and their family represent, in many ways, a modern family in Baku, which continues to honour cultural traditions.

We are on our way to Nasiya Khala, Ilgar's mother, to join a family get-together and a traditional Novruz dinner with Plov a rice dish with lamb, dried fruits, chestnuts and caramelised onions - and the seven different Novruz sweets - dried fruits and pastries - for dessert. It is the last Tuesday before the final Novruz celebration on 21 March, evening rush hour in Baku and the roads are packed with cars. Passing the temporary chaos composed of cracked concrete, dust and redecorated, luminous old buildings along the streets, the line of vehicles makes its way through the city. I am sitting next to Elnara in the back of Ilgar's SUV. He is driving his flashy black car, which fits perfectly into the scenery of Baku's streets, full of the latest models of prestigious brands in black or white. The interior of the car is spacious. I am feeling the soft leather of the seats press against my skin. Elnara and Ilgar are chatting about meeting the family. Elnara holds their little daughter Leyla on her lap. Her arms are wrapped around the small body, rocking her in gentle moves. Novruz Bayram has been constantly on our minds for the past four weeks. I have spent hours watching Elnara, her mother or one of her aunts preparing different sweets and decorations for the holiday. As I think about the upcoming evening, I, too, feel excited. We are finally close to the big celebration of Novruz, after all the preparation and talking about it.

I meet Elnara's gaze and smile at her. She beams back at me - as always. Rocking her little girl from left to right she asks:

"You know what is special about our holiday?"

It was a rhetorical question, because she keeps on talking without waiting for my answer.

"We adults don't do anything special, like the children, who are chasing around for sweets. But we are all feeling special." She halts and chuckles before she continues.

"Everybody is just in a good mood. We are kind of shining from inside." A smile flits across her face and as she is saying this, I imagine spotting a glimpse of her inner gleam of light. I have to grin.

"Do you feel like this on other holidays as well?", I ask.

She shakes her head.

"For me it has always been Novruz Bayramı. Today my mum and my aunt cooked Bakhlava together. They said it was a pity I couldn't be there to cut it. I always cut the Bakhlava...", she pauses, “... but with the baby...?!" Her voice sounds wistful now. I imagine her preparing Bakhlava with her mum and aunt - one of three kinds of pastries families in Azerbaijan prepare for Novruz Bayramı. How they would carefully stack thin layers of pastry, nuts, and honey to build a thick, flat carpet of the finest Bakhlava; how they would place shapely whole nuts on top of the last layer; and how Elnara would cut the Bakhlava into regular diamond shapes. I can feel how she would have loved to celebrate her personal Novruz ritual this year as well (field notes Elisabeth from 18 March 2014, Baku).

In this moment of affective encounter, the different bodies in the car, the memory of rituals, a smile, words and the recollection of a taste converge and allow for the becoming of something else: a momentary indulgence in the joyfulness of Novruz Bayrami. Pleasure and longing fill the air as the car is carrying the passengers closer to the meeting with their loved ones. Elnara relishes in contemplating Novruz Bayram - in imagining meeting her family, cooking together, savouring the sweetness of Bakhlava. I, too, indulge in the affection, the radiant joy drawing me in.

The vignette depicts how embodiment becomes a central feature of national affection. Embodied practices emerging in this momentary configuration of different objects and bodies constitute visceral feelings of national enjoyment. Bodily activities such as Elnara's memory of the different steps of preparing Bakhlava and the imagined action of cutting the Bakhlava link up with her smile, and rocking her daughter in gentle moves with her arms wrapped around her. Likewise, my perception of bodily comfort, as I am settled in the spacious automobile, while the space outside the car looks cramped and filthy, adds to my happiness. The affection stimulates the momentary emergence of past experiences through the somatic reminiscence of the pleasure in the actual practice of cooking and eating.

This corporeal enjoyment fuses with a felt national belonging at the point where affection stimulates the becoming of the idea that an imagined community of Azerbaijanis is likewise thrilled by merging into Novruz rituals and indulging in food specially prepared for this occasion. In the vignette, Elnara refers to an imagined "we" of other people, joining her in celebrating Novruz. This "we" merges her family with an imagined community of adults and children, pictured as sharing the same feelings for the Novruz holiday and carrying out the same rituals. The euphoric feelings constituting this "we"-hood, however, remain rooted in violent and painful struggles over national independence from the Soviet rule that restricted the celebration of Novruz Bayrami.

The family as the small-scale equivalent of the national body (Wilkinson, 2013) is the realm where the celebration of the Novruz holiday is placed. People perceive the Novruz festivities as the central national, non-political, and non-religious holiday in Azerbaijan. Considering the importance of the holiday and its celebration within families reveals how the space of family refuges becomes linked up with the intimate nation space (Caluya, 2011). In the instance described in the vignette bodies carry out what society expects from them including the reproduction of dominant gender and family norms as mother, father, daughter or son, celebrating Novruz with specific rituals, within the family and at a certain time and most importantly the "promise of happiness" (Ahmed, 2010) of this family encounter. In this happiness about Novruz Bayramı, the nation comes to live as something positive and desirable. Accordingly, Novruz Bayramı becomes a national object in a swirl of shared joy in moments of affective encounter. The nation here is reproduced through the intimate space of the family turning into a "felt community" (Ahmed, 2004a, p. 101) that emerges in moments of national affection. Feelings of deprivation or threat that might likewise emerge from encountering materially produced representations of Novruz Bayramı, however, remain excluded.

Interestingly, Elnara's enjoyment is twofold: she enjoys the national speciality while at the same time her enjoyment remains incomplete. Her wistful remembering of past Novruz celebrations reveals how the enjoyment of being a mother to her child and of celebrating Novruz the way she used to are both lacking and contradictory. This shows how bodies resonate with affective encounters in multiple ways resulting from differences in bodily becomings. Since she had a child, Elnara has faced the celebration of the Novruz holiday from an unfamiliar perspective. She feels trapped in a mood of conflicting sentiments making her miss the bodily practices of cutting Bakhlava at the same time as she deeply loves her child. The celebrations of Novruz Bayram become a 
gendered affective experience. My excitement about the upcoming festivities reveals how, as a woman, I am becoming part of a female "we" aligned with Elnara, her mother and her aunts who are preparing the special Novruz pastries, dishes and decorations.

In identifying Novruz Bayramı as a distinct holiday and Bakhlava as a pastry cooked for a special occasion, the national meaningfulness of the moment evolves through a shared visceral knowledge. The affective becoming of bodies and objects intensifies the dynamics of national signification. The visceral enjoyment of the moment would be less passionate if people did not share their understanding of celebrating a certain holiday. At the same time, people would become less joyfully attached to the national holiday if it was just about the authoritative imposition of a specific national ideology. The annual celebration of Heydar Aliyev's ${ }^{4}$ birthday on 10 May, for instance, brims over with official meaning making, but lacks in corporeal conviviality. Even though the birthday is celebrated throughout the country, people rejoice less in it than in Novruz Bayramı. I learned that civil servants are forced to attend the ceremonies. Some parents like to take their children to the Heydar Aliyev square in the city centre of Baku because they can visit the elaborate flower decorations installed there for this day for free. But, apart from that, people increasingly resent the excessive staging of Heydar Aliyev's gloriousness. Consequently, the two holidays evoke different degrees of belonging to an imagined community of Azerbaijanis. While celebrating Novruz Bayram, however, the Azerbaijani nation becomes through the idea of a shared and visceral euphoria that allows for a unification of people.

Thus, signification intertwines with affection. Meaning vanishes without affection, and affection, in return, remains absent without sense making of past experiences inscribed in the bodily traces of becoming. With Ahmed (2004b, p. 7), a feeling of national belonging is neither inscribed in distinct bodies nor allocated to specific places. It rather becomes in moments of affective encounter activating bodily marks of past becomings. National belonging as well as alienation become a felt force in the moment a body's experience encounters foreshadowing, memories, imagined practices as well as corporeal presence in a certain place at a certain time with other bodies around.

\section{Conclusion}

This paper has proposed the concept of an affective nationalism as the banal affirmation of the national through momentary encounters of different bodies and objects. It contributes to current debates around nationalism and affective geographies in a threefold way:

First, we propose on a conceptual level to pay more attention to the affective dimension of nationalism. This does not mean abandoning the study of mundane objects and practices and the meanings they carry. Yet, it does mean enquiring in greater depth into the corporeal work those objects and practices do to create a community where different bodies resonate with each other. Affective nationalism expands the existing body of work interested in banal, embodied and emotional nationalisms by emphasising the importance of the multiplicity of bodies and encounters in flows of constant becomings. Affective nationalism sees nationalism as an everyday experience, including as well as excluding differently marked bodies to different extents into or from a national community in moments of affective encounters through embodying, sharing, enjoying or detesting what feels national. We engage in this paper with the affective dimension of nationalism on the basis of a conceptual framework that brings into concert a Deleuzian ontology of encounter focusing on dynamics of bodily becomings with feminist scholarship on difference, emotion and embodiment. In so doing, the paper acknowledges how different bodily becomings result from the multiple bodily capacities to affect and to be affected. We argue that psychoanalytical and feminist approaches offer rich toolkits to engage with the affective, embodied and visceral dimensions of mundane practices of nationalism.

Second, along the case of Azerbaijan, we show on an empirical level how a national community emerges in moments of affective encounter. The ethnographic material reveals how people feel attached to or disconnected from an imagined nation space, precisely because affective practices trigger or do not trigger a corporeal enjoyment connected to the idea of a national uniqueness respectively a bodily sense of alienation. What makes the case of Azerbaijan interesting and the study of the affective dimension of national identification relevant is that despite the omnipresent attempt of an elite-led nationalism, people experience feelings of national belonging or alienation through bodily encounters between different people, objects and places in everyday life. Those encounters occur in arbitrary ways and are often physically detached from national symbolisms such as the hymn, the flag or the picture of the president. Our analysis has demonstrated how a commemoration event makes for the becoming of a male martyrdom and how the performance of a national holiday and feelings for it changes for a young mother at different stages in her life course.

Third, by proposing a methodological approach that enables capturing and presencing moments of affective encounter through ethnographic field research and the production of written vignettes, we encourage further discussions on how the affective can be empirically studied. In this exploration the positionality of the researcher's diverse bodies warrants particular reflection. Since the affective capacities of bodies involved in the research process influence what attracts the researcher's attention and what remains neglected, taking affective moments in the research process seriously asks for an increased awareness of somatic traces of affection in the researcher's affected bodies through seeing, smelling, hearing, touching or feeling. Despite the arbitrary incommensurability of bodies' affective capacities, bodies can stimulate and be disturbed in similar ways. Operating in similar systems of meaning making, thus, allows bodies to resonate with each other and to communicate belonging as well as exclusion through affections. Feminist geographers have pioneered reflexive methodologies attuned to bodies, experience and feelings. Affective nationalism asks for putting them to work.

\section{Acknowledgements}

We would like to thank Martin Müller for his invaluable comments and editorial support on drafts of this article. We are also very grateful to thoughtful critiques and helpful suggestions of two anonymous referees. Elisabeth is indebted to her informants in Azerbaijan for their trust, openness and willingness to engage in this research project and to share their personal experiences.

\section{Endnotes}

${ }^{1}$ Being aware of the tensions between geographies of emotion and geographies of affect many observe within the discipline (cf. Colls, 2012; Pile, 2010; Wetherell, 2012), we consider emotional and affective geographies not as separate but interlinked conceptual and methodological arguments (Bondi, 2005b; Schurr, 2014; Tolia-Kelly, 2006; Waterton \& Watson, 2013). Concentrating on either of the terms then results from highlighting different aspects of affective and emotional being.

2 The first author of the paper has started to experience Azerbaijan and to research social dynamics in the country since 2007. Among other things, she has mainly worked with local NGOs and in a local university in Ganja.

${ }^{3}$ All names in this paper have been changed.

${ }^{4}$ From 1993 until his death in 2003, Heydar Aliyev was president of the Republic of Azerbaijan. He is the father of incumbent president Ilham Aliyev. 


\section{References}

Adey, P. (2011). 'Ten thousand lads with shining eyes are dreaming and their dreams are wings': Affect, airmindedness and the birth of the aerial subject. Cultural Geographies, 18(1), 63-89. http://dx.doi.org/10.1177/1474474010377670.

Ahmed, S. (2001). The organisation of hate. Law and Critique, 12(3), 345-365. http:// dx.doi.org/10.1023/A:1013728103073.

Ahmed, S. (2004). The cultural politics of emotion. London; New York: Routledge.

Ahmed, S. (2004). Collective feelings or, the impressions left by others. Theory, Culture \& Society, 21(2), 25-42. http://dx.doi.org/10.1177/0263276404042133.

Ahmed, S. (2007). A phenomenology of whiteness. Feminist Theory, 8(2), 149-168. http://dx.doi.org/10.1177/1464700107078139.

Ahmed, S. (2010). The promise of happiness. Durham, London: Duke University Press.

Airriess, C., Hawkins, M., \& Vaughan, E. (2012). Situating banal nationalism, the culture wars, and civil religion: Governing localized geographies of national identity in Indiana. Social \& Cultural Geography, 13(1), 49-67. http://dx.doi.org/ 10.1080/14649365.2011.635801.

Anderson, B. (1991). Imagined communities: Reflections on the origin and spread of nationalism (Revised Edition). London, New York: Verso.

Anderson, B. (2014). Encountering affect: Capacities, apparatuses, conditions. Farnham: Ashgate.

Batuman, B. (2010). The shape of the nation: Visual production of nationalism through maps in Turkey. Political Geography, 29(4), 220-234. http://dx.doi.org/ 10.1016/j.polgeo.2010.05.002.

Beissinger, M. R. (2002). Nationalist mobilization and the collapse of the Soviet state. Cambridge: Cambridge University Press.

Benwell, M. C., \& Dodds, K. (2011). Argentine territorial nationalism revisited: The Malvinas/Falklands dispute and geographies of everyday nationalism. Political Geography, 30(8), 441-449. http://dx.doi.org/10.1016/j.polgeo.2011.09.006.

Berlant, L. (1997). The queen of America goes to Washington city: Essays on sex and citizenship. Durham, London: Duke University Press.

Berlant, L. (2008). The female complaint: The unfinished business of sentimentality in American culture. Durham, London: Duke University Press.

Billig, M. (1995). Banal nationalism. London: Sage.

Blunt, A. (1999). Imperial geographies of home: British domesticity in India, 1886-1925. Transactions of the Institute of British Geographers, 24(4), 421-440. http://dx.doi.org/10.1111/j.0020-2754.1999.00421.x.

Bondi, L. (2005). The place of emotions in research: From partitioning emotion and reason to the emotional dynamics of research relationships. In J. Davidson, L. Bondi, \& M. Smith (Eds.), Emotional geographies (pp. 231-246). Aldershot: Ashgate.

Bondi, L. (2005). Making connections and thinking through emotions: Between geography and psychotherapy. Transactions of the Institute of British Geographers, 30(4), 433-448. http://dx.doi.org/10.1111/j.1475-5661.2005.00183.x.

Bondi, L. (2014). Understanding feelings: Engaging with unconscious communication and embodied knowledge. Emotion, Space and Society, 10(February), 44-54. http://dx.doi.org/10.1016/j.emospa.2013.03.009.

Braidotti, R. (1994). Nomadic subjects. New York: Columbia University Press.

Braidotti, R. (2002). Metamorphoses: Towards a materialist theory of becoming. Cambridge, Malden: Polity.

Braidotti, R. (2003). Becoming woman: Or sexual difference revisited. Theory, Culture \& Society, 20(3), 43-64. http://dx.doi.org/10.1177/02632764030203004.

Bryant, R. (2005). The soul danced into the body: Nation and improvisation in Istanbul. American Ethnologist, 32(2), 222-238. http://dx.doi.org/10.1525/ ae.2005.32.2.222.

Butz, D., \& Besio, K. (2009). Autoethnography. Geography Compass, 3(5), 1660-1674. http://dx.doi.org/10.1111/j.1749-8198.2009.00279.x.

Caluya, G. (2011). Domestic belongings: Intimate security and the racial politics of scale. Emotion, Space and Society, 4(4), 203-210. http://dx.doi.org/10.1016/ j.emospa.2010.11.001.

Carter, S., \& McCormack, D. P. (2006). Film, geopolitics and the affective logics of intervention. Political Geography, 25(2), 228-245. http://dx.doi.org/10.1016/ j.polgeo.2005.11.004.

Colls, R. (2012). Feminism, bodily difference and non-representational geographies. Transactions of the Institute of British Geographers, 37(3), 430-445. http:// dx.doi.org/10.1111/j.1475-5661.2011.00477.x.

Crang, M., \& Tolia-Kelly, D. P. (2010). Nation, race, and affect: Senses and sensibilities at national heritage sites. Environment and Planning A, 42(10), 2315-2331. http://dx.doi.org/10.1068/a4346.

de Spinoza, B. (1883). The ethics. Translated by; R.H.M.; Elwes. Mineola, New York: Dover Publications.

Darling, J. (2010). 'Just being there...': Ethics, experimentation and the cultivation of care. In B. Anderson, \& P. Harrison (Eds.), Taking-place: Non-representational theories and geography (pp. 241-260). Farnham: Ashgate.

De Waal, T. (2003). Black garden: Armenia and Azerbaijan through peace and war. New York, London: New York University Press.

Deleuze, G. (1988). Spinoza: Practical philosophy. San Francisco: City Lights Books.

Deleuze, G., \& Guattari, F. (1987). A thousand plateaus. Translated by; Brian; Massumi. Minneapolis: University of Minnesota Press.

Deleuze, G., \& Guattari, F. (1994). What is philosophy? London; New York: Verso.

Dewsbury, J. D. (2010). Performative, non-representational, and affect-based research: Seven injunctions. In D. DeLyser, S. Herbert, S. Aitken, M. Crang, \& L. McDowell (Eds.), The SAGE handbook of qualitative geography (pp. 321-334). London: SAGE Publications Ltd.
Dittmer, J. (2014). Geopolitical assemblages and complexity. Progress in Human Geography, 38(3), 385-401. http://dx.doi.org/10.1177/0309132513501405.

Dowler, L., \& Sharp, J. (2001). A feminist geopolitics? Space and Polity, 5(3), 165-176. http://dx.doi.org/10.1080/13562570120104382.

Ely, M., Vinz, R., Anzul, M., \& Downing, M. (1997). On writing qualitative research: Living by words. London, Bristol: Falmer Press.

England, K. (2003). Towards a feminist political geography? Political Geography, 22(6), 611-616. http://dx.doi.org/10.1016/S0962-6298(03)00065-9.

Faria, C. (2013). Staging a new South Sudan in the USA: Men, masculinities and nationalist performance at a diasporic beauty pageant. Gender, Place \& Culture, 20(1), 87-106. http://dx.doi.org/10.1080/0966369X.2011.624591.

Faria, C. (2014). Styling the nation: Fear and desire in the South Sudanese beauty trade. Transactions of the Institute of British Geographers, 39(2), 318-330. http:// dx.doi.org/10.1111/tran.12027.

Faria, C., \& Mollett, S. (2016). Critical feminist reflexivity and the politics of whiteness in the 'field'. Gender, Place \& Culture, 23(1), 79-93. http://dx.doi.org/ 10.1080/0966369X.2014.958065.

Fluri, J. L. (2008). Feminist-nation building in Afghanistan: An examination of the Revolutionary Association of the Women of Afghanistan (RAWA). Feminist Re view, 89(1), 34-54. http://dx.doi.org/10.1057/fr.2008.6.

Fortier, A.-M. (2010). Proximity by design? Affective citizenship and the management of unease. Citizenship Studies, 14(1), 17-30. http://dx.doi.org/10.1080 13621020903466258

Hardt, M. (2001). The art of organization: Ontological assemblages and political assemblages in Spinoza. In G. Genosko (Ed.), Deleuze and Guattari: Critical as sessments of leading philosophers (Vol. 1, pp. 376-393). London; New York: Routledge.

Hyndman, J. (2004). Mind the gap: Bridging feminist and political geography through geopolitics. Political Geography, 23, 307-322.

Jones, R., \& Deforges, L. (2003). Localities and the reproduction of Welsh nationalism. Political Geography, 22(3), 271-292. http://dx.doi.org/10.1016/S0962 6298(02)00096-3.

Jones, B., \& Ficklin, L. (2012). To walk in their shoes: Recognising the expression of empathy as a research reality. Emotion, Space and Society, 5(2), 103-112. http:// dx.doi.org/10.1016/j.emospa.2010.10.007.

Jones, R., \& Merriman, P. (2009). Hot, banal and everyday nationalism: Bilingual road signs in Wales. Political Geography, 28(3), 164-173. http://dx.doi.org/ 10.1016/j.polgeo.2009.03.002.

Kaschl, E. (2003). Dance and authenticity in Israel and Palestine: Performing the nation. Leiden, Boston: Brill.

Kingsbury, P. (2011). The World Cup and the National Thing on Commercial Drive, Vancouver. Environment and Planning D: Society and Space, 29(4), 716-737. http://dx.doi.org/10.1068/d4410.

Koch, N. (2013). Sport and soft authoritarian nation-building. Political Geography, 32(January), 42-51. http://dx.doi.org/10.1016/j.polgeo.2012.11.006.

Leib, J. (2011). Identity, banal nationalism, contestation, and North American license plates. Geographical Review, 101(1), 37-52. http://dx.doi.org/10.1111/j.19310846.2011.00071.x.

Lobo, M. (2010). Negotiating emotions, rethinking otherness in suburban Melbourne. Gender, Place \& Culture, 17(1), 99-114. http://dx.doi.org/10.1080 09663690903522446

Longhurst, R., Ho, E., \& Johnston, L. (2008). Using 'the body' as an 'instrument of research': Kimch'i and Pavlova. Area, 40(2), 208-217. http://dx.doi.org/10.1111/ j.1475-4762.2008.00805.x.

Lorimer, H. (2005). Cultural geography: The busyness of being 'more-than-representational'. Progress in Human Geography, 29(1), 83-94.

Massumi, B. (2002). Parables for the virtual: Movement, affect, sensation. postcontemporary interventions. Durham, London: Duke University Press.

Mayer, T. (Ed.). (1994). Women and the Israeli occupation: The politics of change. London; New York: Routledge.

Mayer, T. (Ed.). (2000). Gender ironies of nationalism: Sexing the nation. London: Routledge.

Mayer, T. (2004). Embodied nationalisms. In L. A. Staeheli, E. Kofman, \& L. J. Peake (Eds.), Mapping women, making politics: Feminist perspectives on political geography (pp. 153-167). New York, London: Routledge.

McClintock, A. (1995). Imperial leather: Race, gender and sexuality in the colonial contest. New York: Routledge.

McClintock, A., Mufti, A., \& Shohat, E. (Eds.). (1997). Dangerous liaisons: Gender, nation, and postcolonial perspectives. Minneapolis: University of Minnesota Press.

McCormack, D. P. (2003). An event of geographical ethics in spaces of affect Transactions of the Institute of British Geographers, 28(4), 488-507. http:// dx.doi.org/10.1111/j.0020-2754.2003.00106.x.

McDowell, L. (1999). Gender, identity and place: Understanding feminist geographies. Minneapolis: University of Minnesota Press.

Moss, P. (1999). Autobiographical notes on chronic illness. In R. Butler, \& H. Parr (Eds.), Mind and body spaces: Geographies of illness, impairment and disability (pp. 155-166). London: Routledge.

Müller, M. (2011). Market meets nationalism: Making entrepreneurial state subjects in Post-Soviet Russia. Nationalities Papers, 39(3), 393-408.

Müller, M. (2015). More-than-representational political geographies. In J. Agnew, V. Mamadouh, A. Secor, \& J. Sharp (Eds.), The Wiley-Blackwell companion to political geography (pp. 409-423). Malden: Wiley-Blackwell.

Naroditskaya, I. (2005). Azerbaijani mugham and carpet: Cross-domain mapping. Ethnomusicology Forum, 14(1), 25-55. http://dx.doi.org/10.1080/ 
17411910500088361.

Nash, C. (2000). Performativity in practice: Some recent work in cultural geography. Progress in Human Geography, 24(4), 653-664. http://dx.doi.org/10.1191/ 030913200701540654.

Navaro-Yashin, Y. (2009). Affective spaces, melancholic objects: Ruination and the production of anthropological knowledge. Journal of the Royal Anthropological Institute, 15(1), 1-18. http://dx.doi.org/10.1111/j.1467-9655.2008.01527.x.

Nelson, D. M. (1999). A finger in the wound: Body politics in quincentennial Guatemala. Berkeley, Los Angeles: University of California Press.

Ó Tuathail, G. (2003). 'Just out looking for a fight': American affect and the invasion of Iraq. Antipode, 35(5), 856-870. http://dx.doi.org/10.1111/j.14678330.2003.00361.x.

Paasi, A. (1996). Territories, boundaries, and consciousness: The changing geographies of the Finnish-Russian border. Chichester: Wiley.

Pain, R. (2009). Globalized fear? Towards an emotional geopolitics. Progress in Human Geography, 33(4), 466-486. http://dx.doi.org/10.1177| 0309132508104994.

Pain, R., Panelli, R., Kindon, S., \& Little, J. (2010). Moments in everyday/distant geopolitics: Young people's fears and hopes. Geoforum; Journal of Physical, Human, and Regional Geosciences, 41(6), 972-982. http://dx.doi.org/10.1016/ j.geoforum.2010.08.001.

Penrose, J. (2011). Designing the nation. Banknotes, banal nationalism and alternative conceptions of the state. Political Geography, 30(8), 429-440. http:/ dx.doi.org/10.1016/j.polgeo.2011.09.007.

Pile, S. (2010). Emotions and affect in recent human geography. Transactions of the Institute of British Geographers, 35(1), 5-20.

Proudfoot, J. (2010). Interviewing enjoyment, or the limits of discourse. The Professional Geographer, 62(4), 507-518. http://dx.doi.org/10.1080/ 00330124.2010 .501271$.

Radcliffe, S. A. (1996). Gendered nations: Nostalgia, development and territory in Ecuador \{1\}. Gender, Place \& Culture, 3(1), 5-22. http://dx.doi.org/10.1080/ 09663699650021918.

Radcliffe, S. A. (1999). Reimagining the nation: Community, difference, and national identities among indigenous and mestizo provincials in Ecuador. Environment and Planning A, 31(1), 37-52. http://dx.doi.org/10.1068/a310037.

Raento, P., \& Brunn, S. D. (2005). Visualizing Finland: Postage stamps as politica messengers. Geografiska Annaler. Series B, Human Geography, 87(2), 145-164. http://dx.doi.org/10.1111/j.0435-3684.2005.00188.x.

Rose, G. (1997). Situating knowledges: Positionality, reflexivities and other tactics Progress in Human Geography, 21(3), 305-320. http://dx.doi.org/10.1191/ 030913297673302122

Sayfutdinova, L. (2014). The alley of martyrs: Deaths, memory and the nation. Caucasus Analytical Digest, 66, 14-16.

Schurr, C. (2013). Performing politics, making space: A visual ethnography of political change in Ecuador. In Erdkundliches Wissen (Vol. 152). Stuttgart: Franz Steiner Verlag.

Schurr, C. (2013). Towards an emotional electoral geography: The performativity of emotions in electoral campaigning in Ecuador. Geoforum; Journal of Physical, Human, and Regional Geosciences, 49(October), 114-126. http://dx.doi.org/ 10.1016/j.geoforum.2013.05.008.

Schurr, C. (2014). Emotionen, Affekte und non-repräsentationale Geographien. Geographische Zeitschrift, 102(3), 148-161.

Schurr, C., \& Abdo, K. (2016). Rethinking the place of emotions in the field through social laboratories. Gender, Place \& Culture, 23(1), 120-133. http://dx.doi.org/ 10.1080/0966369X.2014.970138.

Sharp, J. (2009). Geography and gender: What belongs to feminist geography? Emotion, power and change. Progress in Human Geography, 33(1), 74-80. http:/ dx.doi.org/10.1177/0309132508090440.

Smith, G., Law, V., Wilson, A., Bohr, A., \& Allworth, E. (1998). Nation-building in the Post-Soviet borderlands: The politics of national identities. Cambridge: Cambridge University Press.
Smith, S. H. (2012). Intimate geopolitics: Religion, marriage, and reproductive bodies in Leh, Ladakh. Annals of the Association of American Geographers, 102(6), 1511-1528.

Smith, S. H. (2016). Intimacy and angst in the field. Gender, Place \& Culture, 23(1), 134-146. http://dx.doi.org/10.1080/0966369X.2014.958067.

Staeheli, L. A. (2001). Of possibilities, probabilities and political geography. Space and Polity, 5(3), 177-189.

Thrift, N. (2004). Intensities of feeling: Towards a spatial politics of affect. Geografiska Annaler. Series B, Human Geography, 86(1), 57-78. http://dx.doi.org/ 10.1111/j.0435-3684.2004.00154.x.

Tokluoglu, C. (2005). Definitions of national identity, nationalism and ethnicity in Post-Soviet Azerbaijan in the 1990s. Ethnic and Racial Studies, 28(4), 722-758. http://dx.doi.org/10.1080/01419870500092951.

Tolia-Kelly, D. P. (2006). Affect - An ethnocentric encounter? Exploring the 'universalist' imperative of emotional/affectual geographies. Area, 38(2), 213-217.

Tyner, J., \& Henkin, S. (2015). Feminist geopolitics, everyday death, and the emotional geographies of Dang Thuy Tram. Gender, Place \& Culture, 22(2), 288-303. http://dx.doi.org/10.1080/0966369X.2013.879109.

Valiyev, A. (2005). Azerbaijan: Islam in a Post-Soviet Republic. Middle East Review of International Affairs, 9(4), 1-13.

Warren, S. D. (2009). How will we recognize each other as Mapuche? Gender and Ethnic identity performances in Argentina. Gender \& Society, 23(6), 768-789. http://dx.doi.org/10.1177/0891243209351293.

Waterton, E. (2013). Heritage tourism and its representations. In R. Bushell, R. Staiff, \& S. Watson (Eds.), Heritage and tourism: Place, encounter, engagement (pp. 64-84). London: Routledge.

Waterton, E., \& Dittmer, J. (2014). The museum as assemblage: Bringing forth affect at the Australian War Memorial. Museum Management and Curatorship, 29(2), 122-139. http://dx.doi.org/10.1080/09647775.2014.888819.

Waterton, E., \& Watson, S. (2013). Framing theory: Towards a critical imagination in heritage studies. International Journal of Heritage Studies, 19(6), 546-561. http:// dx.doi.org/10.1080/13527258.2013.779295.

Watson, A. (2012). I crashed the boat and wept: Localizing the 'field' in critical geographic practice. Emotion, Space and Society, 5(3), 192-200. http:/ dx.doi.org/10.1016/j.emospa.2011.10.004.

Wetherell, M. (2012). Affect and emotion: A new social science understanding. London: Sage.

Wetherell, M., McCreanor, T., McConville, A., Barnes, H. M., \& le Grice, J. (2015). Settling space and covering the nation: Some conceptual considerations in analysing affect and discourse. Emotion, Space and Society, 16(August), 56-64. http://dx.doi.org/10.1016/j.emospa.2015.07.005.

Wilkinson, E. (2009). The emotions least relevant to politics? Queering autonomous activism. Emotion, Space and Society, 2(1), 36-43. http://dx.doi.org/10.1016/ j.emospa.2009.05.007.

Wilkinson, E. (2013). Learning to love again: 'broken families', citizenship and the state promotion of coupledom. Geoforum; Journal of Physical, Human, and Regional Geosciences, 49(October), 206-213. http://dx.doi.org/10.1016/ j. geoforum.2013.02.012.

Wood, N. (2002). 'Once more with feeling': Putting emotion into geographies of music. In L. Bondi, H. Avis, R. Bankey, et al. (Eds.), Subjectivities, knowledges, and feminist geographies: The subjects and ethics of social research (pp. 57-71). Lanham, MD: Rowman \& Littlefield.

Woodward, K. (2014). Affect, state theory, and the politics of confusion. Political Geography, 41(July), 21-31. http://dx.doi.org/10.1016/j.polgeo.2014.04.001.

Yea, S. (2015). Girls on film: Affective politics and the creation of an intimate antitrafficking public in Singapore through film screenings. Political Geography, 45(March), 45-54. http://dx.doi.org/10.1016/j.polgeo.2014.08.009.

Yuval-Davis, N. (1997). Gender and nation. London: SAGE Publications.

Zhemukhov, S., \& King, C. (2013). Dancing the nation in the North Caucasus. Slavic Review, 72(2), 287-305. http://dx.doi.org/10.5612/slavicreview.72.2.0287. 